\title{
Semantic representation of similes (based on the Ukrainian, English and Polish languages).
}

\author{
Mariana Oleniak ${ }^{*}$ \\ Vasyl`Stus Donetsk National University, Ukraine
}

\begin{abstract}
Since simile in this paper is understood as a figure of speech in which two essentially unlike things are compared and not only as a construction corresponding to the formula $X$ is like $Y$, the borderline between the semasiological (from form to content) and onomasiological (from content to form) approaches in respect to the analysis of simile is considered to be crucial. The article is devoted to the analysis of the existing formulas for simile that enumerate the elements in the surface structures of most similes and to the elaboration of a formula that would reflect the essence of the relationship of simile elements regardless of their formal expression. Taking into account existing linguistic studies of similes as well as the author's own understanding of the problem, simile components are described which also have a symbolic reflection in the aforementioned universal formula for similes. Employing the method of conceptual analysis as well as the methods of description and interpretation, modelling and coding, the author devises a new formula for simile, representing all four of its constituents (a tenor, a vehicle, a comparison marker and a commonly shared salient feature). The devised formula is further subjected to analysis for the possibility of being applied to all formal types of simile. The presented formula of a universal character is essential to identify and analyse different types of similes without limiting research to the formations of a certain model. The formula is labelled universal because it characterizes similes regardless of their forms and languages in which they are used.
\end{abstract}

\section{Key words}

simile, formula, comparative relations, surface structure, implicature

\section{Introduction}

Since simile in the paper is described from the perspective of a semantic representation of the coding of similarity between notions, and not from that of a correspondence to a particular linguistic structure, the differentiation between a semasiological and onomasiological approach in simile analysis is essential. A retrospective look at the centuries-old study of simile proves that the semasiological (from form to content) approach is not able to cover all types of simile by providing a single formula. Classifying a certain phenomenon as a simile only if it corresponds to a particular structure leads to the study of certain types of simile and simultaneous neglect of other types. The lack of awareness of the necessity of finding a universal formula that would fit the characteristics of all structural types of simile results from a focus on its typical form, which only partially represents the phenomenon. Linguists tend to agree on the structural diversity of simile (Leech and Short, 2007, p.51; O'Donoghue, 2009, p.128; Pierini, 2009, p.28) but do not offer methodological principles for semantic representation of its structural diversity. An onomasiological (from content to form) approach seems to be more universal in this case - it

\footnotetext{
*Address for correspondence: Mariana Oleniak, Faculty of Foreign Languages, Vasyl Stus Donetsk National University, 600-richchia 21, Vinnytsia, Ukraine. E-mail: maryana@mail.org
} 
eliminates the exceptional nature of some unproductive similes, preventing exceptions to the rule. The author chooses this approach because it enables the consideration of a universal formula for any simile, regardless of its formal expression. An onomasiological approach makes it possible to consider simile in terms of the plurality of its possible structures, a set of different manifestations of a single notion, each of which requires understanding and study. This paper is an attempt to broach the problem of the possible existence of a universal formula for simile irrespective of the language it is used in. Regardless of the form, simile always has internal ordering principles of comparative relations between its components, which are not always apparent in the surface structure. Notwithstanding the formal characteristics of a simile, the inherent comparative relations of a tenor and a vehicle represent a constant feature when analysing its implicature (Grice, 1961), as simile is not so much about "what is said" but about "what is meant" (Davidson, 1984, pp. 254; Searle 1993, p. 96; Chiappe and Kennedy, 2001, pp. 270-71). This internal ordering principle is a kind of rule according to which notions are juxtaposed in simile - a semantic representation of the idea of figurative similarity. This is a key hypothesis in the further analysis of existing formulas for simile and the creation of a new universal formula for all similes. Since the author employs a purely onomasiological approach to the problem of simile, the rules of simile semantics seem to be completely outside the grammar of a particular language and belong to aspects of general cognition. Simile in the paper is understood as a poetic comparison structurally different from but functionally similar to metaphor on the one hand and structurally similar to but functionally different from a literal comparison on the other hand (Carston, 2002; Fogelin, 2011; Gargani, 2014). It is a juxtaposition of notions based on their similarity caused by conceptual associations between the concepts (Lakoff, 2008). The author claims that these conceptual associations rest on stereotypical information associated with the vehicle, which is the archetype of a salient feature commonly shared with a tenor, being a unifying key factor in semantic representation of similes.

\section{Methods}

The analysis of the semantics of similes in terms of their implicature involves the application of a modelling method that reduces all formal diversity of similes to some typical models that do not depend on the lexical meaning of their components. Since the empirical material of the paper is exemplified in three languages, I used reductive analysis to assert equivalence among the studied languages. At the point of a simile implicature description I provided a detailed description of a typical interpretation of an example utterance. I employed conceptual analysis to modify existing formulas, namely constructive analysis, allowing the introduction of an occasionally implied element of a simile which is a salient feature shared by a tenor and a vehicle. While explaining the formula elements representing certain simile components, I used the descriptive method as well as the methods of modelling and coding. After I devised the new formula, I tested the possibility of its application to similes of different structural types; the positive results of application gave me the grounds to speak about a complex approach to the study of the problem of semantic representation of similes.

\section{New approach to old controversies}

\subsection{Existing formulas for simile}

As a figurative device, simile displays a particular kind of similarity between a topic and a vehicle; it cannot be taken literally unlike reversible literal comparisons (Glucksberg and Keysar, 1990, pp. 3-4, 16; Gardani, 2014, p.226); simile is very context-sensitive and never independent of associations of a speaker / listener which help to identify a commonly shared salient feature (Tversky, 1977, pp. 329-332; Ortony, 1998, pp. 342-353). Taking into account the fact that the formal means of simile expression are quite diverse (morphological - by means of suffixes, e.g. a catty fellow, describing a person who is as spiteful/mean as a cat; word-building - by means of creating words, usually compounds and occasionalisms, e.g. to T-bone describing a particular type of car crash; lexical - by means of using notional words with the meaning of similarity, e.g. to look like, to resemble etc., syntactic - by means of employing a comparative structure as...as, as if, as though), ${ }^{1}$ all of them convey the invariant core

\footnotetext{
${ }^{1}$ Different means of simile expression were described in the article (2015) Способи утворення образного порівняння в англійській, українській та польській мовах. Типологія мовних значень у діахронічному та зіставному аспектах. Вінниця:ДонНУ, рр.78-85.
} 
meaning of a comparison based on similarity, and we can talk about the necessity to search for a binding principle, a kind of code that would justify classifying all of these formally different structures as one and the same concept - simile. This code, a formula, would reveal the universal nature of simile semantics regardless of the language in which it is used and, thus, the form it is expressed by. As simile in this paper is understood as an asymmetric formation with semantics prevailing over the form from the point of view of the theory of linguistic sign asymmetry (Gak, 2000), the common basis for the creation of a formula should be a semantic-oriented approach of simile analysis. Of course, this is not in consideration of the lexical meaning of separate simile components, but in consideration of the semantics of a different level - an implicature of simile.

The decisive factor in decoding utterances is attributed to implicature in Gricean and Neo-Gricean investigations. Bach and Harnish (Bach and Harnish, 1979) connect pragmatics with "whatever information is relevant, over and above the linguistic properties of a sentence", considering communication successful "if the hearer identifies his [speaker's] intention" (Bach and Harnish, 1979, p.15). Discussing the conversational implicature of metaphor and related tropes Levinson (1983) emphasizes the necessity of a pragmatic approach to their analysis. He introduces the notion of the "'connotational penumbra' of the expressions involved, the incidental rather than the defining characteristics of words, and knowledge of the factual properties of referents and hence knowledge of the world in general" (Levinson, 1983, p. 150). He stresses the importance of inferring some analogy in detecting implicit features in the process of simile interpretation (Levinson, 1983, p.155).

Not being dependent on relevance theory, the author's understanding of semantic representation of similes can also be easily integrated into a relevance-theoretical approach, in which poetic uses of language are considered to be "weak implicatures" and according to which "loose talk, metaphor and hyperbole are merely alternative routes to achieving optimal relevance. Whether an utterance is literally, loosely or metaphorically understood will depend on the mutual adjustment of context, context and cognitive effects in order to satisfy the overall expectation of relevance" (Sperber and Wilson, 2006, p.619). The author cannot but agree with Magdalena Sztencel (2018, p.4) who questions the viability of the definition of explicit-implicit distinction in formal terms, describing it as a "psycho-processing distinction". I believe that the semantic level of simile description should comply with the ideas of the language philosophers Fodor (1998), Gibbs (2002), and Burton-Roberts (2007; 2013), who claim that utterances should be interpreted in respect to the semantics of thought, debating the necessity of a canonical linguistic semantics. It is not only a linguistically shared but also a conceptually shared experience that is crucial for a proper interpretation of similes.

Realizing that the search for a typical model is required in order to exclude the possibility of intuitive research while analysing simile, linguists singled out a concrete criterion for simile recognition, devising the formula $X$ is like $Y .^{2}$ Quite a number of modifications of this formula were presented in Bronner's comments on Dandi's investigation of Sanskrit simile in which 32 varieties of simile were singled out. A more universal formula that is not based on a particular language is the formula A (r) B, devised by Malykh (2012, p.189), in which $A$ represents a tenor, $B$ stands for a vehicle, and $r$ is a formal indicator of simile. The existence of standard formulas for similes is, undoubtedly, the result of the fruitful and hard work of many linguists; however, some shortcomings of such coding of comparative semantics in simile cannot be ignored. First, the aforementioned formulas can be applied both to some similes and to logical comparisons, which are fundamentally different formations. Secondly, if in the formula $X$ is like $Y$ the lexical meaning of the middle element like presupposes comparison, contrast or analogy, the $r$ element in the formula A (r) B, which is used in logic to denote relations, does not indicate the actually comparative nature of the relations symbolized by itself in any way. Third, none of the formulas indicate the grounds of simile, those common features on the basis of which the notions are compared. The insufficiency of the traditional formula $X$ is like $Y$ as well as A (r) B formula can easily be exemplified by the sentence

\footnotetext{
${ }^{2}$ In Russian and Ukrainian specialist literature this formula is usually represented by the coordinate symbols N1 and $\mathrm{N} 2$ instead of $\mathrm{X}$ and $\mathrm{Y}$, so the traditional formula for simile in Soviet and post-Soviet linguistic literature is $\mathrm{N} 1+$ like+N2. As this difference is negligible, I will use the traditional formula $X$ is like $Y$ in this article, as it is more widely used in English-language scholarship.
} 
(1) She sings like an angel.

where $\mathrm{X}$ is HER SINGING, like is a simile indicator, $\mathrm{Y}$ is the SINGING OF AN ANGEL. Interpreting this sentence, we understand that the speaker does not just communicate the fact of HER SINGING and the SINGING OF AN ANGEL. He intends to describe the EXTRAORDINARY BEAUTY OF HER SINGING; in other words, indirectly, by means of comparison, the speaker emphasizes the high quality of singing, which is, in fact, that implied common feature shared by the conceptual representations of WOMAN and ANGEL, and which is not reflected in the aforementioned formulas in any way. The same is true for similes in two other languages under study. For example,

(2) Ukr.: Вона була худа, як тріска

'She was thin as a rail'.

(3) Pol.: Na autostradzie samochody mkna niczym blyskawice

'On the highway race cars run like lightning bolts'.

The notion of EXCESSIVE THINNESS in (2), which is the essence of the expression, is not represented in the formula $X$ is like $Y$, where $\mathrm{X}$ is SHE, as - the simile indicator, and $\mathrm{Y}$ - A RAIL. In (3) there is no intention to communicate the information about cars and lightning, except for the ULTRA-HIGH SPEED of the two, the common feature shared both by RACE CARS and LIGHTNING, which is not reflected in the formula $X$ is like $Y$, where $\mathrm{X}$ would be RACE CARS, niczym - simile indicator, $\mathrm{Y}$ - LIGHTNING BOLTS.

The aforementioned shortcomings of existing formulas - namely: 1) the possibility of being applied to both similes and comparisons; 2) the ambiguity of the middle simile indicator interpretation and 3) the impossibility of marking the grounds of simile - caused linguists to introduce an additional element into the formula for simile which was to represent the ground. Thus, Yu. I. Yudina (2010, p.32) uses the following formula for simile: $\{\mathrm{A}+\mathrm{C}+\mathrm{B}+\beta\}$, where $\mathrm{A}$ is a tenor; $\mathrm{B}$ is a vehicle, $\mathrm{C}$ is a ground; $\beta$ is a formal indicator of simile. Since this formula contains a separate specific element to indicate the ground it seems to be more sophisticated than the formulas $X$ is like $Y$ and A (r) B. Despite being useful in the study of certain aspects of simile, this formula has some drawbacks and is not suitable for the complex analysis of similes, since, like other formulas, it does not denote the relation of similitude between the tenor and the vehicle. In fact, it does not indicate any relations at all inasmuch as the plus sign represents addition, which can hardly be attributed to simile. Moreover, the positioning of the formula components, with the final position of a comparison marker, is also misleading as the formula in no way shows that $\mathrm{A}$ and $\mathrm{B}$ possess some of $\mathrm{C}$, making them units of the same level with no relationship or explicated degrees of intensity whatsoever. The formula does not show that the elements are similar and how they are similar.

The analysis of the three formulas for simile (X is like $\mathrm{Y}$; $\mathrm{A}(\mathrm{r}) \mathrm{B} ;\{\mathrm{A}+\mathrm{C}+\mathrm{B}+\beta\}$ ) calls for a discussion. First, the use of the plus sign "+" is not justifiable as it does not reflect the comparative relations within simile. In the case of the semantic representation of simile, it would be appropriate to devise a universal formula, which would show not only the compositional structure of a simile, but also the special relations among its constituent elements. Second, the conventional formula $X$ is like $Y$ may serve as an abstract code not only for a simile but also for other syntactical units, such as a literal comparison in English and even more remote from comparison structures in Slavonic languages.

(4) Eng.: You (X) are tall like your brother (Y);

(5) Ukr.: Я приймаю ие (X) як ліки (Y)

'I take it $(\mathrm{X})$ as a medicine' $(\mathrm{Y})$;

(6) Pol.: Jak zdobyć prace (X) jako nauczyciel (Y)?

'How does one get a job (X) as a teacher(Y)?';

Thirdly, the purely formal approach which reflects only the surface structure of some types of similes, albeit the most productive ones, neglects certain marginal types of simile such as Eng.: deaddrunk [IMMOBILE AND INSENSIBLE BECAUSE OF ALCOHOL LIKE A DEAD PERSON]; Ukr.: дівка-вогонь 'girl-fire' [A VERY ENERGETIC GIRL]; Pol.: drzewiasty 'like a tree', only because they do not correspond 
to the traditional formula, having no separate formal indicator of comparison. This fact forces some researchers to deliberately abandon the analysis of certain empirical data. Thus, Markus (2010, p.214) avoids the analysis of certain similes, dismissing them as "camouflaged" similes, merely on the grounds that they do not meet traditional formal criteria.

The simile of inequality poses another challenge for the traditional formula $X$ is like $Y$. Without modification the $X$ is like $Y$ formula can be applied only to similes of equality as Saara Nevanlinna (1993) defines them (e.g. She is like the goddess of beauty or She is as beautiful as the goddess of beauty). It is unable to comply with a different type of simile, namely a simile of inequality, since the latter will inevitably demand its alteration. It is not possible, for example, to apply the $X$ is like $Y$ formula to the similes

\section{(7) Her lips are redder than roses.}

\section{Roses are less red than her lips.}

If we insisted on doing so, we would have to change the traditional formula to $X$ is more than $Y(7)$ or $X$ is less than $Y(8)$ or $X$ is not like $Y(7),(8)$.

The insufficiency of the formula $X$ is like $Y$ is also mentioned in the work of O'Donoghue (2009, p. 128): "Whilst metaphor theorists tend to keep to instances which depend upon the use of the copula form, which can be so handily adapted to suit either metaphor or simile - ' $\mathrm{X}$ is $\mathrm{Y}$ ' versus ' $\mathrm{X}$ is like $\mathrm{Y}$ ' - the scope of the linguistic form of both metaphor and simile is a great deal more broad". Leech and Short (2007, p. 51) separate conventional similes of the form $X$ is like $Y$ from quasi-similes which are actualized by different linguistic constructions, without providing a universal formula for the latter. In addition, the use of traditional formulas distracts linguists from the essence of simile, the purpose of which, in my opinion, is not to compare two objects, but to highlight some important feature, that is the ground of simile, something which is meant by simile. If the aim of simile were the comparison of two objects, it would be read literally as a comparison, which would make it absolutely uninformative (see explanation of the examples [12], [13], [14]).

The abovementioned formulas enumerate the surface structure elements of simile only, while the most essential information rendered by simile is, more often than not, hidden in its implicature.

\subsection{Constituents of similes}

The study of any construction demands, first and foremost, a specification of its constituting elements. The term simile is stereotypically associated with a syntactic form containing a certain indicator (Eng.: like, as; Ukr.: як; Pol.: jak, niczym) and corresponding to the formula $\mathrm{X}$ is like Y. However, at times, simile can be a more complex and more flexible formation that does not fit into the above frame.

Despite the fact that formal means of the expression of simile have been described in specialist literature in detail, there is still some disagreement, especially as far as the quantity of its elements is concerned: it ranges from one to four components. Among the advocates of a one-member grammatical structure of simile are Ogoltsev (1978) and Nazarian (1998). In early studies, conducted by Cheremysina (1976), a simile with no explicit tenor is classified as a one-member construction, such as:

(9) Eng.: as happy as a cricket [VERY HAPPY];

(10) Ukr.: блідий, як смерть

'pale as death' [VERY PALE];

(11) Pol.: jeść jak wróbelek

'to eat like a sparrow' [TO EAT VERY LITTLE]

In Russian and Polish scholarship (Klemensiewicz, 1937; Shyrokova, 1960; Chernysheva, 1970; Telia, 1986; Kopylenko, 1989; Kunin, 1996; Skommer, 2011, and others) it is stated that constructions of this type are traditionally characterized as two-member ones. Most linguists consider them threemember constructions (Hulyha, 1969; Shendels, 1969; Ashchurova, 1970; Iskanderova, Shenko, 1972, 1980; Aleksandrova, 1981; Fedorov, 1985; Berkov, 1996; Shapovalova, 1998; M'yasnyankina, 1999; Prokopchuk, 2000; Nikolaeva, 2002; Kucherenko, 2003; Mizin, 2008). In addition, there are linguists 
who consider these units to be four-member ones (Sakamoto, 1983; Shchepka, 2008; Zamay, 2008; Devyatova, 2010; Lapshyna, 2010; Yudina, 2010). Analysing the number of components of simile, one should take into account the fact that constructions such as (9), (10), (11) entered the language paradigm as set phrases and are seemingly three-member units containing

1) the vehicle: cricket (9), death (10) and sparrow (11);

2) formal indicator of simile: as (9), як (10) and jak (11);

3) an explicitly or implicitly expressed ground: HAPPY (9), PALE (10), TO EAT LITTLE (11).

However, their three-member status can only be justified outside the sentence. In speech there always appears a referent, a tenor, compared to the vehicle (fourth element of simile), which makes such constructions four-member formations. These features are crucial not only for frozen similes, but for any simile.

As for the ground, it does not mean that if not explicitly stated, it is an optional element of a simile. It is usually the implicature of a simile, typically realizing the speaker's main purpose in uttering the simile. Talking about the aim of simile I adhere to a Gricean (1961) approach to meaning according to which it derives from what is meant by the speaker and should be analysed in terms of the speaker's intentions.

Consider the following example:

\section{Eng.: Watching that movie was like watching paint dry.}

The sentence does not communicate any facts about the FILM or PAINT; it describes the film as VERY BORING though BORING is not explicitly stated, making the conceptual content of the simile differ from its linguistic-semantic content. In fact, it is crucial to realize the presence of an implicit ground here to understand the sentence adequately. Communication is successful only because the recipient has access to stereotypical assumptions about how boring it is to watch paint dry, so he/she projects it onto the FILM in question, and therefore understands that the FILM is not interesting. Thus, during comprehension of the utterance in (12), the feature shared by the FILM and the process of observing DRYING PAINT is mentally explicated, which proves the presence of this element of simile (the ground) in its implicature. The same is true for the other two languages under analysis:

(13) Ukr.: В неї брови, як шнурочки

'She has eyebrows like strings'.

(14) Pol.: Marek skacze niczym kangur

'Marek jumps like a kangaroo'.

The sentence (13) is not about EYEBROWS and STRINGS, it is about THE BEAUTY AND NEATNESS OF THIN EYEBROWS; although BEAUTY AND NEATNESS is not explicitly mentioned, it is nevertheless obvious in the conceptual content of the utterance. While formulating a simile, the speaker counts on the associative thinking of the recipient, who, following a logical chain "strings are thin and neat, so, accordingly, EYEBROWS in question are thin and neat as well, and thin and neat eyebrows are beautiful" mentally explicates the ground (thinness) and draws corresponding conclusions concerning the beauty of the EYEBROWS implied by the simile. In (14) the sentence is not about MARK or a KANGAROO, it is about Marek's SKILFUL JUMPING with SKILFUL not explicitly stated but conceptually implied. MAREK and KANGAROO are compared only on the basis of a shared feature: they both jump rather deftly. This shared feature is known both by the author and by the recipient of the statement as it is stereotypically associated with a KANGAROO, and without it the meaning of the sentence would be completely different. By stereotypicality I mean a universally accepted opinion, image or generalization based on a nation's experience. I do not use the term "prototype" as a synonym for vehicle, for I understand prototypicality as a draft or a sample of something under development or an original object which is the basis for some other objects. Prototype, in my opinion, presupposes creation of something similar to the sample or original notion, while stereotype presupposes some generally agreed characterization highlighting a certain salient feature. 
Examples (12), (13) and (14) above demonstrate that simile is not the aim of communication but a means to impart some implicature, to produce a poetic effect on readers / listeners by stimulation of their associative thinking and under no circumstances are they to be read literally.

If to claim that a certain unit is an optional element of something (in this case it is the ground the author is referring to, since many linguists consider simile a three-element structure consisting of a tenor, a comparison marker and a vehicle), the removal of this unit should in no way affect the analysed structure. This experiment does not work in the case of simile. It can be easily demonstrated by wording a simile using notions that a priori do not have any common feature, which will make the simile destined for communicative failure. For example:

\section{*My job is as wet as an echo}

does not make any sense since the compared referents have no chemical, physical or any other kind of properties that could be shared, and an ECHO is not stereotypically associated with being WET. The absence of a common shared feature between the compared notions deprived the formation of its simile status making it a preposterous word combination only formally appearing like a simile since there is no simile without similarity. Moreover, the very possibility of removing this commonly shared characteristic proves its presence and, hence, the status of a separate element of simile, as it is impossible to remove something that does not exist. Thus, I consider that, despite being occasionally implicitly expressed, the ground is a compulsory separate element of the simile structure.

Therefore, the author takes the view that a typical simile consists of four elements: 1) a tenor, 2) a vehicle (as Richards, 1937, defined them); 3) a ground; 4) a formal indicator.

\subsection{Universal formula for similes}

To devise a universal formula for simile it is important to take into account all of its categorical features, namely the presence of: 1) a heterogeneous referent (tenor) and standard of comparison (vehicle); 2) the common feature stereotypically associated with the vehicle that they share to a different extent (ground);

3 ) the comparative relations that arise based on their similarity.

So, to implement the first condition (the presence of a heterogeneous referent [tenor] and standard of comparison [vehicle]) it is desirable not to use coordinate elements (N1 and N2), but different ones - A and B. Coordinate elements can be used for logical comparisons where referents from the same scope of reality are juxtaposed, for example:

(16) Ukr.: Ти - як твій тато - дуже розумний

'You are - like your dad - very smart'.

In this case both the referent indicated by the lexeme you and the referent indicated by the word combination your father are conceptually similar: both are people of the same sex and both are typical bearers of characteristic male features, hence, they can indeed be coded by the same letters with a different index number, i.e. N1 and N2. Figurativeness, on the other hand, arises only because the tenor and the vehicle of simile belong to genetically different kinds of object, phenomenon or creature, as in

(17) Ukr.: Не вір тій хитрій, мов лисиия, жіниі

'Do not believe that cunning as a fox woman'.

Comparing a WOMAN with a FOX, we juxtapose qualitatively different beings - a human and an animal - heterogeneous referents belonging to different scopes of reality, so it would be logical to designate them with different letters such as A and B.

To implement the second condition (the presence of the common feature that tenor and vehicle share to a different extent [ground]) in the formula for simile I introduce a character that would symbolize the ground of a simile, which can be any other (different from A and B) letter, for example $n$. The introduction of the common feature marker $(n)$ into the formula is important for the extraction of a simile implicature which is a key factor in its correct interpretation, since $n$ represents the implied properties of the juxtaposed entities inherent to a different degree in each of them. This point is crucial as even if a simile is recognized it is not always easily understood (Chiappe and Kennedy, 2001, pp. 270-71). As 
a commonly shared feature is characteristic of compared referents to different extents, (a woman is cunning, but a fox is extremely cunning being the stereotype of cunningness in particular cultures), the formula must foreground the possession of a feature shared by both tenor and vehicle but exemplified by each to a different degree. Binary operations of multiplication and exponentiation enable it: the extent of WOMAN'S CUNNINGNESS can be denoted by multiplication (An), and the extent of a FOX's CUNNINGNESS - by exponentiation $\left(\mathrm{B}^{\mathrm{n}}\right)$. Multiplication and exponentiation are suitable operations in the formula for simile since multiplication corresponds to a repeated adding, and exponentiation corresponds to $\mathrm{n}$-fold multiplication which naturally indicates that An will always be quantitatively less than $\mathrm{B}^{\mathrm{n}}$, i.e., the "amount" of a shared feature in A will always be less than the "amount" of a shared trait in B taking into account that all the variables in the formula cannot be equal to zero or any number since they represent a certain existing concept.

To implement the third condition (the comparative relations that arise based on tenor-vehicle similarity) one should correctly understand the purpose of any formula. The Dictionary of Ukrainian Language gives the following definition of the word "formula": "Formula is a designation of relations of any values, elements, etc. expressed by letters, numbers, or symbols" (SUM-11, p. 625). Thus, any formula is to denote, first of all, the relations between its elements, if such relations exist, and not to simply enumerate constituents. The traditional formula $X$ is like $Y$, unfortunately, does not show these relations, nor does any other existing formula for simile, since the semantics of simile is not equal to the sum total of the meanings of its components. Simile is an independent linguistic notion whose goal is to highlight the commonly shared trait on the basis of which the referents are juxtaposed (see the analysis of [12], [13], [14]). Accordingly, the use of the "+" symbol in the formula for simile seems inappropriate: the general meaning of simile is not the sum total of the meanings of its elements, it is the result of explicit or implicit emphasis of a commonly shared feature that stands out on the basis of their similarity. For example, in (12) emotions during the film are equated with emotions which arise while waiting for paint to dry [approximately equal to them]; in (13) eyebrows shape is equated with strings [approximately equals to them]; in (14) Marek's ability to jump is equated with kangaroo's skill in the process [approximately equal to it]. Thus, in devising the formula for simile, it seems more appropriate to resort to a character which is used in mathematics, logic and other exact sciences to denote two approximately equal values, the difference between which can be ignored in this particular matter. Such a symbol of approximate equality is " $\sim$ ". Using the symbol of approximate equality in the universal formula for simile, in fact, makes it possible to show the type of relations between the tenor and the vehicle.

Thus, the general formula for simile will look as follows: $\mathrm{An} \approx \mathrm{B}^{\mathrm{n}}$, where

- A is a tenor;

- $\mathrm{n}$ is a trait commonly shared by the tenor and the vehicle;

- $\quad$ $\approx$ " is a symbol encoding similarity between the tenor and the vehicle;

- $\mathrm{B}$ is a vehicle;

An and $\mathrm{B}^{\mathrm{n}}$ shows the possession of a common feature by the tenor and the vehicle to different extents.

When we talk about similes or any other means of figurative language we consider the linguistic representation of notions from extra-linguistic reality which are not numeric variables (they cannot be equal to a positive / negative number or zero), but actions, states, objects, properties, phenomena, etc. Bearing that in mind, one should understand that, as a semantic representation of simile, the formula is not destined to calculate something resulting in a particular number but to display the type of relationship between its components possessing a common quality to a different degree. Since tenors and vehicles possess a commonly shared quality to a different degree, the notion represented by simile grounds should a priori be gradable: stereotypically, strings are neater than eyebrows (13), a kangaroo jumps more skillfully than a boy (14), a fox is more cunning than a woman (17) etc. It is as if there is a scale in similes within the grounds, in these particular cases - scales for neatness and beauty in (13), skillful jumping in (14), cunningness in (17) etc. Thus, this commonly shared feature cannot represent any numeric value: there is not a scale for 0 or 1 or any other number. Nothing can be "more zero than something / less zero than something" or "more one than something / less one than something", so, unlike in mathematics, when applied to simile, this formula cannot a priori infer that $n$ equals to 1 or any other number.

The salient feature (ground) shared by a tenor and a vehicle is considered in the paper to be an important element in understanding simile implicature. With that in mind, while interpreting similes, 
especially the open ones (Margolis, 1957; Beardsley, 1981), the formula will prove its usefulness. For example, George Eliot's words He was like a cock who thought the sun had risen to hear him crow should be interpreted as follows:

- A PERSON seemingly has nothing in common with a COCK at first glance, so why is HE (A) compared to a COCK (B)? Is it to emphasize pride in his character since a COCK is usually a symbol of pride because of its appearance, or is it to say that the person is an early bird? In the provided example the person is compared not to just any cock but to one who thinks that the sun rises to hear its crowing. What typical feature (n) does such a way of thinking reflect? Since only a highly conceited being would think that the sun rises for its sake, the phrase describes the cock as an archetype of conceitedness, as a standard of an excessively favourable opinion of one's abilities. Thus, stating that a man is like a cock, the speaker makes them almost equal $(\approx)$ in this way telling us that what he has in mind is a very conceited person. Consequently, the aim of the speaker was to describe an EXTREMELY CONCEITED PERSON and he used the simile as a means to poetically do so.

The formula $\mathrm{An} \approx \mathrm{B}^{\mathrm{n}}$ does not just show that the tenor and the vehicle are similar, it describes how they are similar, the issue discussed by Mordechai Z. Cohen (Cohen, 2003) following the works of Davidson (Davidson, 1984, pp. 253-257) and Searle (Searle, 1993, p.96), who asserts that X is like Y really means that $\mathrm{X}$ has the features $\mathrm{A}, \mathrm{B}, \mathrm{C} \ldots$, which are associated with $\mathrm{Y} ; \mathrm{X}$ is like $\mathrm{Y}$ says only that $\mathrm{X}$ and $\mathrm{Y}$ are similar not indicating how they are similar, which is the point of simile. The point of simile is understood to be what the speakers intentionally communicate, the implicature of the simile: "In the case of simile, we note what it literally says, that two things resemble one another; we then regard the objects and consider what similarity would, in the context, be to the point." (Davidson 1984, p. 254)

The formula will help to identify similes which do not necessarily correspond to traditionally discussed linguistic patterns $X$ is like $Y$ or as $X$ as $Y$. It covers also covert or compressed similes as Pierini defines them (Pierini, 2009, p.28), which can be further seen when the formula is applied to different formal types of simile.

\section{Results}

The application check of the devised formula $\mathrm{An} \approx \mathrm{B}^{\mathrm{n}}$ for all four types of similes (morphological, word building, lexical and syntactic) will prove its effectiveness.

\subsection{Application check of the devised formula $A n \approx B^{n}$ for morphological types of simile}

Morphologically formed similes by means of ablative case in Ukrainian and Polish, and the suffixes ish, -like, -some, -y in English; -видний, -подібний in Ukrainian; -waty, -asty, -y in Polish, can be demonstrated by such examples:

(18) Ukr.: Хлопчик блискавкою побіг до сусіда

'The boy lightningly [auth.: VERY RAPIDLY, quickly like lightning] ran to the neighbour'

(19) Eng.: Her childish [IMMATURE] behaviour was inappropriate in the situation

(20) Pol.: Nie podoba mi się ten nowy pajakowaty model

'I don't like this new spiderlike [in the FORM OF A SPIDER] model'

In (18) the tenor of the simile is the BOY'S RUNNING, the vehicle is LIGHTNING (in ablative case), and the ground is RASHNESS and the SPEED OF MOVEMENT, or, in accordance with the universal formula

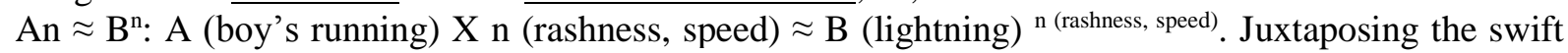
and fast movements of both BOY and LIGHTNING, we understand that they can be similar [approximately equal] only to some extent, because the speed of the lightning will be higher than the boy's in any case, so the boy's running possesses the feature of speed [multiplication, which is a repeated adding] to a certain extent, but lightning possesses the same feature to a much greater extent [increased at an exponential rate]. In (19) where the sentence communicates IMMATURE BEHAVIOUR of the subject, the formula $\mathrm{An} \approx \mathrm{B}^{\mathrm{n}}$ reflects the simile relations in this way: $\mathrm{A}$ (behaviour of a subject) $\mathrm{X} \mathrm{n}$ (immaturity) $\approx \mathrm{B}$ (child's behaviour) ${ }^{\mathrm{n} \text { (immaturity) }}$. Comparing the behaviour of an adult with a child's behaviour, one understands their similarity [approximate equality], but still, it is obvious that 
the immaturity is inherent to a lesser extent in the adult than in the child. Hence, the presence of a corresponding trait in the adult woman manifests itself more faintly [multiplication, which is a repeated adding] than in the child [immaturity is increased at an exponential rate]. In (20) the speaker aims at explication of a form of a certain model that is similar [approximately equal] to the shape of a spider, but in any case, this model possesses the formal features of a spider to a lesser extent than the arachnid, because it is, actually, a model of something, and not the spider itself. This different degree of the shared trait I denote in the formula by multiplication in the case of the model and exponentiation in the case of the spider.

In examples (18), (19), and (20) of the morphologically formed simile the ground is not explicitly stated in the surface structure, but it is the reason for the use of simile in these contexts in the first place, since it represents their implicature. Therefore, the indication of it in the formula is necessary and consistent.

\subsection{Application check of the devised formula $A n \approx B^{n}$ for word-building types of simile}

The word-building formation of simile, which is the formation of compounds and sometimes occasionalisms or authorial neologisms, can be represented by the following examples:

(21) Ukr.: Його жінка далеко не делікатна, це баба-грім

'His woman is far from being delicate, she is a woman-thunder [A VERY PHYSICALLY STRONG AND BRAVE WOMAN]'

(22) Eng.: I started washing his grass-green trousers after painting

(23) Pol.: Cyberycerz jest jednym z nieologizmów Stanisława Lema

'Roboknight [ROBOT, SIMILAR TO A KNIGHT] is one of Stanislav Lem's neologisms'.

Examples from all three languages (21), (22), (23) correspond to the universal formula for simile $\mathrm{An} \approx \mathrm{B}^{\mathrm{n}}$. The Ukrainian composite баба-грім ('woman-thunder') not denoting a female or thunder as such, but AN EXTRAORDINARILY PHYSICALLY POWERFUL AND BRAVE WOMAN I code as follows:

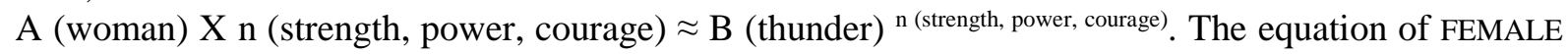
to THUNDER [their approximate equality] still presupposes their non-identity in terms of possessing a shared feature to different extents. The physically measurable power of even the strongest woman in the world will be less than the power of thunder, so the formula, comparing these two elements, attributes not such great power to a woman [multiplication, which is a repeated adding of strength] as the one attributed to thunder [increased at an exponential rate]. Similarly, the universal formula for simile can be used for (22), where the colour of trousers is compared with GREEN grass: A (colour of trousers) $\mathrm{X} \mathrm{n}$ (green) $\approx \mathrm{B}$ (grass) ${ }^{\mathrm{n} \text { (green) }}$. The fabric of trousers is green [repeated adding of greenness] which makes it look like [approximately equal to] the colour of grass with its natural pigmentation [greenness increased at an exponential rate]. ROBOKNIGHT in (23) is a robot, which looks like [approximately equals to] a knight due to its traits [repeated adding]; still, a knight possesses the same feature but to a greater extent [exponentiation].

In the above-described word-building formation of simile in the three languages the ground can be expressed either explicitly or implicitly, but it does not affect the status of the unit under analysis: it is a simile based on the shared trait of the tenor and vehicle in any case, which is reflected in the universal formula for simile $\mathrm{An} \approx \mathrm{B}^{\mathrm{n}}$.

\subsection{Application check of the devised formula $A n \approx B^{n}$ for lexically formed similes}

Lexically formed similes, which involve the use of notional words with the seme of comparison / similarity, that perform the function of the predicate in the sentence, can be demonstrated by the following examples:

(24) Ukr.: Ця скеля має форму обличчя

'This rock has the shape of a face' 
(25) Eng.: Her eyes remind me of deep blue lakes

(26) Pol.: Twoja córka przypomina mi piękny kwiatek

'Your daughter reminds me of a beautiful flower'

Each of these examples (24), (25), (26) can be abstractly represented by the formula. Thus, in (24) the formula $\mathrm{An} \approx \mathrm{B}^{\mathrm{n}}$ I interpret as follows: $\mathrm{A}$ (rock) $\mathrm{X} \mathrm{n}$ (shape of the face) $\approx \mathrm{B}$ (human face) ${ }^{\mathrm{n} \text { (shape of the }}$ face). The FORM OF THE ROCK is compared to [approximately equals to] a human face based upon similarity. Features of a face are typical for HUMAN FACE [at an exponential rate] but to a lesser extent intrinsic in the rock [repeatedly added] because of its physical properties: inequality, roughness, disproportion, etc. In (25), where EYES are compared to LAKES, $\mathrm{An} \approx \mathrm{B}^{\mathrm{n}}$ represents the following

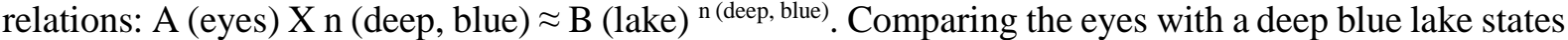
their similarity [approximate equality], and the BLUENESS and the DEPTH of a look manifest themselves in a lesser extent in case of eyes [repeated adding] than the colour and actual depth of the lakes [exponentiation]. The juxtaposition of DAUGHTER with BEAUTIFUL FLOWER in (26) also meets the universal formula for simile: A (daughter) $\mathrm{X} \mathrm{n}$ (prettiness) $\approx \mathrm{B}$ (beautiful flower) ${ }^{\mathrm{n} \text { (prettiness) }}$, where the natural loveliness of a beautiful flower [exponentiation] partially manifests itself in a girl [repeated adding], which allows them to be compared, indicating similarity [approximate equality] between them.

\subsection{The application check of the devised formula $A n \approx B^{n}$ for syntactically formed similes}

A syntactically formed simile, which is realized in comparative constructions, introduced by certain functional words, can be demonstrated by the following examples:

(27) Ukr.: Хлопеиь стояв, наче вкопаний

'The boy was standing as if embedded'

(28) Eng.: Do not look at me as if I am a ghost

(29) Pol.: Powodza się ze mna jak ze zdrajca

'They treat me like a traitor'

A syntactically formed simile is the most typical object of analysis where linguists have repeatedly applied the formula $X$ is like $Y$. I predict that there will be no exceptions to the formula for this type of simile either. Thus, (27) says not so much about the boy or something dug into the ground, but about his IMMOVABILITY, which cannot be denoted by the formula $X$ is like $Y$. It can be easily interpreted by the formula $\mathrm{An} \approx \mathrm{B}^{\mathrm{n}}$, on the other hand: $\mathrm{A}$ (boy's state) $\mathrm{X} \mathrm{n}$ (immovability) $\approx \mathrm{B}$ (embedded object) ${ }^{\mathrm{n} \text { (immovability) }}$. The immovability of the boy and an imbedded object is the basis for comparison, which shows that they are similar in a particular respect, but different in the degree to which they instantiate this property [approximately equal]: the boy is immovable to a lesser extent [immovability is repeatedly added] and an imbedded object - to a greater extent [immovability increased at an exponential rate]. Similarly, (28) communicates GREAT SURPRISE, which can most effectively be described by the formula $\mathrm{An} \approx \mathrm{B}^{\mathrm{n}}$ : A (look) $\mathrm{X} n$ (surprise) $\approx \mathrm{B}$ (seeing a ghost look) ${ }^{\mathrm{n} \text { (surprise) }}$. The look of the subject of the sentence is equated to the look of a man who sees a ghost [approximately equals to] on the ground of surprise, which, actually, manifests itself much more strongly in the situation with a ghost [surprise increased at an exponential rate] than with a man [surprise is repeatedly added]. A DENIGRATING ATTITUDE towards a person is communicated in (29), where A (treatment of the

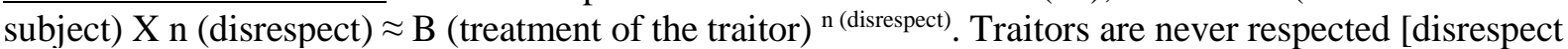
increased at an exponential rate], which makes it possible to compare this attitude [make it approximately equal] to the one, which is displayed towards the object of the sentence [disrespect is repeatedly added]. In these examples (27), (28), and (29) in all three languages only a deep semantic analysis of simile reveals its essence, which cannot be reflected in the traditional formula $X$ is like $Y$. On the contrary, the use of the formula $\mathrm{An} \approx \mathrm{B}^{\mathrm{n}}$ makes it possible to show all of the constituent elements of the simile, clarifying the relationships between them. 


\subsection{Application check of the devised formula $A n \approx B^{n}$ for similes of inequality}

The formula can also be applied to similes of inequality. This suggests that the formula is indeed universal.

(30) She is more beautiful than any goddess of beauty.

\section{Any goddess of beauty is less beautiful than she is.}

The examples (30), (31) have exactly the same content though slightly different connotations: in (30) the speaker praises the EXTRAORDINARY BEAUTY of a woman employing the marker of comparison more, which has a positive connotation, while in (31) apart from praising the extraordinary beauty of the woman, the speaker gives the utterance the somewhat negative connotation of depreciating goddesses of beauty employing the comparative marker less. Whatever the connotations, the examples (30) and (31) not only communicate the physical attractiveness of the woman but also imply an extremely high degree of SPLENDOUR much greater than of any beautiful woman. In these particular cases of a simile of inequality, however, an A symbol will denote the vehicle and a B symbol will denote the tenor, since in the aforementioned examples the concentration of a common feature is higher in the tenor than in the vehicle: goddess of beauty (A) $X \mathrm{n}$ (beautiful) $\approx$ she $(\mathrm{B})^{\mathrm{n} \text { (beautiful) }}$. Unlike the traditional $X$ is like $Y$ formula, the formula $\mathrm{An} \approx \mathrm{B}^{\mathrm{n}}$ does not need to be changed in the case of a simile of inequality.

\subsection{Application check of the devised formula $A n \approx B^{n}$ for extended similes}

The devised formula appears prima facie to be applicable to extended similes or multiple similes with either the same tenor and different vehicles or repeated conceptually similar vehicles, though further indepth research is necessary since there might be some latent challenges. Both extended and multiple similes can apparently fit into the formula sometimes bringing about its modification. The devised formula $\mathrm{An} \approx \mathrm{B}^{\mathrm{n}}$ is the formula for similes with a minimum number of components: three variables (tenor, vehicle, shared quality). Multiple similes presuppose additional components which will cause modification of the formula by means of introducing additional variables, for example:

(32) Her lips were like red roses, like soft petals, like sweet wine.

In (32) there is one tenor (LIPS) and 3 vehicles (ROSES, PETALS, WINE). In this particular case we are dealing with 7 variables (1) LIPS (A), 2) ROSES (B), 3) PETALS (C), 4) WINE (D), 5) REDNESS (n), 6) SOFTNESS $(\mathrm{m}), 7)$ SWEETNESS $(\mathrm{k})$, the last three being commonly shared features). Thus, the formula for this simile will be Anmk $\approx \mathrm{B}^{\mathrm{n}}+\mathrm{C}^{\mathrm{m}}+\mathrm{D}^{\mathrm{k}}$.

Extended similes, usually spanning several lines, represent detailed comparisons specifying the particular nature of the vehicle, for example in Homer's "Illiad":

(33) As when the shudder of the west wind suddenly rising scatters across the water, and the water darkens beneath it, so darkening were settled the ranks of Achaians and Trojans in the plain.

Notwithstanding its extended nature, the simile (33) represents an emotional comparison of the ranks of soldiers (A) to the stormy sea (B) both being fierce and dark (n), corresponding to the formula $\mathrm{An} \approx \mathrm{B}^{\mathrm{n}}$. The extended specification of the nature of the sea darkness ("when the shudder of the west wind suddenly rising scatters across the water") does not bring about an additional variable, it answers the question "Which kind of darkness of the sea is exactly meant?" because water darkness itself can be of different shades: it can be moonlit black on a calm night, reddish or yellowish dark-blue during sunset or of a dirty green-grey colour during a storm. Thus, in (33) the formula does not need to be modified. However, to be certain that the abovementioned formula is always suitable for extended similes further in-depth research needs to be conducted.

The use of the universal formula $\mathrm{An} \approx \mathrm{B}^{\mathrm{n}}$ demonstrates certain advantages because the encoding of the information is: 1) not limited to the enumeration of the simile elements; 2) displays the kind of relations typical only of simile and not of other syntactic structures; 3) can be applied to all forms of simile expression, including word building that enables researchers to analyse empirical data of different types, not just its core; 4) enables linguists to penetrate into the implicature of a simile. 


\section{Conclusion}

Simile is a formation that demonstrates a clear dominance of content over form: speakers resort to simile not because they want to compare two elements, but because they want to emphasize important information that can be displayed by comparing these two elements. This juxtaposition can be expressed by different surface structures with a varying degree of complexity: from lexical to syntactic. Simile is not a narrative about the tenor or the vehicle, it is the signposting of the ground - the commonly shared trait - the explication of which is the only reason for the use of the simile. Simile demonstrates the importance of what is meant (implicature), and not how it is said (surface structure). Thus, the approach to the universal symbolic coding of simile should be based not on the surface structure of certain (though the most common) similes, but on the implicature showing quantitative and qualitative correlation between its components. Accordingly, the formula should not enumerate or add what is on the surface (as in this case it will cover all the syntactic formations of the $X$ is like $Y$ type, which are not limited to simile only) it should reflect what is deep inside the simile, the relations of similitude between the tenor and the vehicle on a specific ground, which at a surface level can be expressed by different formations.

The devised formula is the first attempt to explicate the features associated with the vehicle in the way they are related to the tenor; it is also the first coding of the "point" of simile (the other thing meant) in the case of open or covert simile. The formula is easy to adapt to other languages, as it displays the relations of the simile constituents irrespective of their particular linguistic representation.

\section{Acknowledgement}

I would like to express my sincere gratitude to my supervisor Mykhailo Seniv for his patient guidance and sharing of wisdom during my research. Special thanks also go to my colleagues Svitlana Kryshtal and Olena Biletska for their encouragement and stimulating discussions during the initial stages of preparing the manuscript. I would also like to express my deepest appreciation to the reviewers for their insightful comments and expert advice as well as to the associate editor of the journal, Dr. Štefan Beňuš, for his support.

\section{References}

Aleksandrova, S., 1981. Structural and semantic characteristics of comparative constructions in 16-17 century English. Moscow: Vyssha shkola.

Ashchurova, D., 1970. The linguistic nature of simile in English. Moscow: Vyssha shkola.

Bach, K. and Harnish, R., 1979. Linguistic communication and speech acts. Cambridge, Mass.: MIT Press.

Beardsley, M., 1981. Aesthetics: Problems in the philosophy of criticism. Hackett Publishing.

Berkov, V., 1996. Semantics of comparison and types of its expression. The theory of functional grammar: Quantity. Quality, Spb, pp. $106-154$.

Bilodid, K., 1980. Ukrainian dictionary. «UD - 11». vol. 10. Kyiv: Naukova dumka.

Bronner, Y., 2007. This is no lotus, it is a face: Poetics as grammar in Dandi's investigation of the simile. The poetics of grammar and the metaphysics of sound and sign. Boston: Brill, pp. 91-108.

Bronner, Y., 2012. A question of priority: Revisiting the Bhāmaha-Dandin debate. Indian Philos, 40, no. 1, pp. 67-118.

Burton-Roberts, N., 2007 Varieties of semantics and encoding: Negation, narrowing/loosening and numericals. Pragmatics. Palgrave-Macmillan, pp. 90-114.

Burton-Roberts, N., 2013 Grice and cancellation. Journal of Pragmatics, vol. 48, no. 1, pp. 17-28.

Carston, R., 2002. Thoughts and utterances. Blackwell.

Cheremysina, M., 1976. Russian comparative constructions. Novosibirsk: Izd-vo Novosibirskogo unta.

Chernysheva, I., 1970. The phraseology of modern German. Moscow: Vyssh. shk.

Chiappe, D. and Kennedy, J., 2001. Literal bases for metaphor and simile. Metaphor and Symbol, vol.16, pp. 249-276.

Cohen, M., 2003. Three approaches to biblical metaphor: From Abraham Ibn Ezra and Maimonides to David Kimhi. Leiden: Brill.

Davidson, D., 1978/1984. What metaphors mean. Critical Inquiry, vol.5, no. 1, pp. 31-47. Reprinted in: Davidson, D., Inquiries into truth and interpretation. Oxford: Clarendon Press, pp. 245-264. 
Devyatova, N., 2010. Comparison in a dynamic system of the language. Moscow: URSS.

Fedorov, A., 1985. Figurative speech. Novosibirsk: Nauka.

Fodor, J. A., 1998. Concepts. Where cognitive science went wrong. Oxford: Clarendon Press.

Fogelin, R. J., 2011. Figuratively speaking. Oxford: Oxford University Press.

Gak, V., 2000. The theoretical grammar of the French language. Moscow: Dobrosvet.

Gargani, A., 2014. Poetic comparisons. How similes are understood. Salford: University of Salford.

Gibbs, R. W., 2002. A new look at literal meaning in understanding what is said and implicated. Journal of Pragmatics, vol. 34, pp. $457-486$.

Glucksberg, S. and Keysar, B., 1990. Understanding metaphorical comparisons: Beyond similarity. Psychological Review, vol 97, no. 1, pp. 3-18.

Grice, H. P., 1961. The causal theory of perception. Proceedings of the Aristotelian Society, Supp, vol. XXXV, pp. 121-53.

Hulyha, E. and Shendels, E., 1969. Grammatical and lexical fields in modern German. Moscow: Prosveshchenye.

Iskanderova, I., 1980. The role of the context in revealing the semantics of comparisons. Research of Sentences in German. RHU, pp. 3 - 14.

Kopylenko, M., 1989. General phraseology sketches (phraseological units in the system of the language). Voronezh: Voronezh University Press.

Kucherenko, I., 2003. Syntactical functions of comparative constructions. Topical problems of grammar. Svit, pp. $136-139$.

Kunin, A., 1996. The course on phraseology of modern English. Moscow: Feniks.

Lakoff, G., 2008. The neural theory of metaphor. In: R.W. Gibbs, Jr., ed. The Cambridge handbook of metaphor and thought. Cambridge: Cambridge University Press, pp. 17 - 38.

Lapshyna, O., 2010. Semantic category of similarity in modern Russian. Kharkiv: KhNU.

Leech, G.; Short, M., 2007. Style in fiction. Pearson Education Limited.

Levinson, S. C., 1983. Pragmatics. Cambridge: Cambridge University Press.

Myasnyankina, L., 1999. Interrelation of metaphor and simile in Sholokhov's ideostyle. Ukrainian Bulletin, vol. 5, KhNU, pp. 45-51.

Malykh, L., 2012. The logical formula of a linguistic comparison. Bulletin of ISLU, vol. 1, no. 17, ISLU, pp. 184-191.

Margolis, J., 1957. Notes on the logic of simile, metaphor and analogy. American Speech, Duke University Press, vol. 32, no. 3, pp. $186-189$.

Markus, M., 2010. As drunk as muck. The role and logic of similes in English dialects on the basis of Joseph Wright's English Dialect Dictionary. Studia Neophilologica, vol. 82, pp. 203-216.

Mizin, K., 2008. Psycholinguistic experiment or sociolinguistic monitoring? Epistemological search for axiological phraseology (based on comparative phraseology). Linguistics, vol. 1, KNU, pp. 67 - 79.

Nazarian, A., 1998. Frozen similes in French. Moscow: Vyssh. shkola.

Nevanlinna, S., 1993. The structure of Middle English similes of equality. Early English in the computer age. Explorations through the Helsinki Corpus. Berlin: Mouton de Gruyter, pp. 139-170.

Nikolaeva, A., 2002. Functional and semantic field of comparativity in modern English. Rostov-naDonu.

O'Donoghue, J., 2009. Is a metaphor (like) a simile? Differences in meaning, effect and processing. UCL Working Papers in Linguistics, vol. 21, pp. 125-149.

Ogoltsev, V., 1978. Frozen similes in the system of Russian phraseology. Leningrad: Leningrad University Press.

Ortony, A., 1998. Metaphor and thought. Cambridge: Cambridge Univ. Press.

Pierini, P., 2007. Simile in English: From description to translation. CÍRCULO de Lingüística Aplicada a la Comunicación (clac), vol. 29, pp.21 - 43.

Prokopchuk, L., 2000. The category of comparison and its expression in a simple sentence structure. Kyiv: In-t of Ukr. lang.

Richards, I., 1937. The Philosophy of rhetoric. New York: Oxford University Press.

Searle, J. R., 1993. Metaphor. In: A. Ortony, ed. Metaphor and thought. Cambridge: Cambridge University Press, pp. $83-111$.

Shapovalova, N., 1998. Peculiarities of comparative semantics features in adverbial models. Functional and cognitive manifestations of grammatical structures. IZMN, pp. $57-62$. 
Shchepka, O., 2008. Functional and semantic field of comparativity. Simferopol': Tavriyskyi National University.

Shenko, I., 1972. On relationship between figurative devices (simile and metaphor). The stylistics of Romance and Germanic languages. RTP LGPI, pp. 151-165.

Shyrokova, N., 1960. Types of syntactical constructions with comparative conjunctions in a simple sentence. Kazan`: Yzd-vo Kazansk. Gos. Un-ta.

Sztencel, M., 2018. Semantics, pragmatics and meaning revisited: the case of conditionals. Springer.

Telia, V., 1986. Connotational aspect of nominative unit semantics. Moscow: Nauka.

Tsutomu, S., 1983. On linguistic classification of metaphorical expressions. Descriptive and applied linguistics, vol. 16, pp. 197-208.

Tversky, A., 1977. Features of similarity. Psychological Review, vol. 84, no. 4, pp. 327-352.

Wilson, D. and Sperber, D., 2006. Relevance theory. The handbook of pragmatics. Blackwel Publishing, pp. $607-632$.

Yudina, I., 2010. Similes with an unexpressed module as a means of reader's reflection actualization. Bulletin of Volgograd State University. Series 2, vol. 2, no. 12, pp. 31-35.

Zamai, S., 2008. Functional and semantic category of comparativity and the means of its representation in Russian and English. Bulletin of Adygej State University, vol. 6, pp. 93 - 96. 